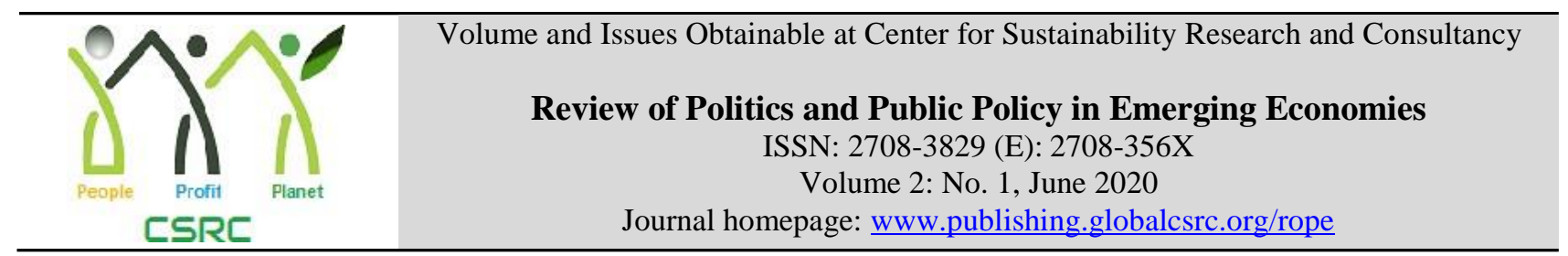

\title{
Interrogating the Nexus between Party Politics and Party Institutionalization in Nigeria
}

\author{
${ }^{1}$ Alfa Patrick Innocent \\ ${ }^{1}$ Department of Social Science and Humanities, The Federal Polytechnich, Idah Kogi State, Nigeria, \\ alfaintellectual@gmail.com
}

\begin{tabular}{l}
\hline ARTICLE DETAILS \\
\hline History \\
Revised format: May 2020 \\
Available Online: June 2020 \\
\\
\hline Keywords \\
Party politics, Party \\
institutionalization, \\
Democracy, Fourth \\
Republic, Democratic \\
Consolidation, Nigeria \\
\hline
\end{tabular}

JEL Classification

$F 5, F 50$

\begin{abstract}
This article critically examines the nature of party politics in Nigeria since the inception of the Fourth Republic. It contends that party politics in Nigeria's Fourth Republic is characterized by dysfunctional evolution of political parties, lack of unity and focus, electoral fraud, lack of internal party democracy, intergovernmental disharmony, political violence, ideological deficit, gross indiscipline and elite antagonism. The article is methodologically conceptual. Relevant secondary data comprising of journal articles, textbooks, workshop papers, and national dailies were consulted. The article discovered that party politics in Nigeria's Fourth Republic is highly defective and volatile, thus forestalling party institutionalization and, by extension, democratic stability. The article concludes with recommendations on how Nigeria's party politics could be redefined to facilitate party institutionalization and improve the quality of democratic governance.
\end{abstract}

Corresponding author's email address: alfaintellectual@ gmail.com

Recommended citation: Innocent, A. P., (2020). Interrogating the Nexus between Party Politics and Party Institutionalization in Nigeria. Review of Politics and Public Policy in Emerging Economies, 2 (1), 9-17

\section{Introduction}

Political parties constitute the foundation of democratic government. They provide the citizens the choice to elect those who would represent them at the local and national level. When the Clifford constitution introduced elective principle in Nigeria in 1922, political parties began to emerge to participate in the electoral process. The first political party, the Nigerian National Democratic Party (NNDP) was formed by Herbert Macaulay in 1923. This, with other political parties, which were formed at that epoch was informed by the need to elect representatives to the few legislative seats allotted to Nigerians by the colonial authorities.

With the attainment of independence in 1960, the political parties which emerged, though offshoots of the parties that operated during the colonial era, exhibited narrow sentiment such as ethnicity and regionalism. The defects of party politics in the First Republic brought a lot of contradictions which led to military intervention in 1966. The collapse of Nigeria's First Republic was followed by recurring 
coups and counter coups.

General Aguyi Ironsi who took over power after the bloody but failed coup of 1966 claimed that the military would not cling to power for long before returning to democratic rule. However, his attempt to foist unitary system on the country was met with stiff resistance and he was killed in a coup which aggravated national crisis. His successor, General Yakubu Gowon attempted to resolve the crisis but did not succeed as a result of mistrust and mutual suspicion among the political class. Misunderstanding between Colonel Ojukwu who was the military governor of the erstwhile Eastern region and General Yakubu Gowon over the granting of regional autonomy to the Eastern region from the federal arrangement snowballed into the unfortunate events that culminated in the outbreak of the civil war in 1967 which ended in January 1970 without the Eastern secessionist bid achieved.

After the cessation of the civil war hostilities, instead of sticking to his earlier promise to return the country to democratic rule in 1976, General Gowon beat a retreat and announced in his independence speech of October 1974 that, politicians, by their conduct, had not learnt enough lessons to be trusted with governance. This attracted a great deal of public opprobrium even within the military circle and his regime was overthrown in 1975. His successor, General Murtala Muhammed was killed in February 1976 and was succeeded by his deputy, General Olusegun Obasanjo who followed the transition timetable religiously and handed over power to the democratically elected government of President Shehu Shagari on October 1 1979. The political parties that participated in party politics in the First Republic were largely engrossed in ethnicity and corrupt practices.

The Murtala/ Obasanjo regime was the first successful attempt at military- supervised transition to democratic governance in Nigeria after independence. Fundamentally, it attempted to entrench an orderly transfer of power from the military to the elected civilians. Efforts were made to promote positive values, political behaviour and political culture that would be in tune with the ideals of multiparty democracy. The choice of parliamentary system was aimed at circumventing the schism associated with opposition politics and provide effective checks against centrifugal pressures. The transition did away with the radical forces of the left and brought the repackaged old bred politicians to power on the assumption that they had learnt their lessons and the character of the transition program had schemed them out from the political process. Though the Second Republic was successfully installed, the military struck again, barely after four years and terminated the regime of President Shehu Shagari.

The Buhari regime that came on board did not promise any return to democratic rule but rather concentrated on actions, which in its view, would resolve the crisis in the system. However, the regime's high handedness and repressive brand of nationalism estranged organised groups, the media and the entire citizenry and was eventually overthrown in August 1985.

When General Babangida seized power in August 1985, he promised to return the country to democratic rule within the shortest time possible. However, he embarked on a tortuous transition program which never ended. He discredited and delegitimized the political class with the claim of embarking on political engineering. Despite the high expectation it generated at the initial stage, Babangida's transition program became a "transition without end". There was constant extension of handover dates, proscribing and lifting of ban on certain categories of politicians tagged radicals, corruption and the cancellation of June 121993 presidential election believed to be free and fair by both domestic and foreign observers made the Babangida regime to become infamous and forced him to 'step aside' on August 271993.

General Abacha sacked the Shonekan led Interim National Government which Babangida handed over power to and abolished all democratic structures of Babangida's political transition. His transition agenda was underpinned by his self transmutation bid as manifested by the masterminded actions of the political parties which eventually adopted him as the sole presidential candidate. Abacha's sudden death on June 81998 brought General Abdulsalami Abubukar to power. General Abubakar's transition 
program commenced in July 1998 and ended on May 291999.

As would be seen in the subsequent sections, the operations of political parties and politicians since the return to democracy do not manifest convincing prospects for party institutionalization, a critical criteria for democratic growth and consolidation. This unfortunate scenario was captured by Ibeanu (2013) "one of the most crucial and yet least developed democratic institutions is the political party system. There are currently 50(which rose to over 63 but now scaled down to 25 in 2013) registered political parties in the country, most of which are an assemblage of people who share the same level of determination to use the party's platform to get power. As such, it is difficult to identify programmes or ideologies. The structure of the political parties is such that internal democracy is virtually absent. The political parties are weak and unable to effectively carry out political education and discipline".

The need to overhaul them for better performance, therefore, becomes exigent and expedient.

\section{Literature Review}

\subsection{Political Parties}

Political parties are the key actors of representative democracy (Hislope \& Mughan, 2012; Thurston,2015). A party is a group of officials or would-be officials who are linked with a sizeable group of citizens in an organisation, a major goal of this organisation is to ensure that its officials acquire power or are maintained in power (Shively, 2001, Hofmeister \& Grabow, 2011).

Political parties are expected to carry out certain roles in a democracy. They perform the role of representation. In organising elections, they perform the task of representation by articulating and aggregating the interests of their members and constituents or sections of the public ( Mainwaring \& Scully, 1995). This is expected to complement the roles of civil societies where they are well developed. They also help in resolving societal conflicts. This is more pertinent in situations where democratic transition is characterised by tacit agreements. With this, the differences of the actors can be resolved to ensure that they build a synergy and work together (O'Donnell \& Schmitter, 2000).

Political parties help in ensuring accountability. In advanced democracies, the leadership is made to account for their actions. This is to ensure they keep their promises to the electorates. In the event that they fail, the chances of the opposition being elected in the next election become brighter ( Hofmeister \& Grabow, 2011).

Political parties facilitate the institutionalization of democracy. Parties are crucial in the entrenchment of democratic norms and ideals. They enhance the quality of constitutional rules as they are vehicles of attitudinal and behavioural change and by implication deepen democratic consolidation (Mainwaring, 1998).

Political parties enhance the legitimacy of government. Parties boost the legitimacy of governance by providing good will to the new democracies so that they do not collapse and revert to authoritarianism (Mainwaring, 1998).

\subsection{Party Institutionalization}

A party is institutionalized if it is represented in the mind of the public and operates as a social organization regardless of its transient leaders and manifest regular modes of behaviour cherished by those that associate with it. (Baer,1993; Sanches, 2014). The three perspectives used here are - stable patterns of 'interparty competition; stable roots in the society; as well as organizational continuity.

Stable patterns of interplay competition was the first indices recognized by Mainwaring (1999). Drawing insights from Sartori (1976), Mainwaring noted that the forms of interaction among political parties symbolize the major hallmark of party systems. This is known through stable patterns of inter 
party competition during elections, in the parliament or governmental levels.

According to Mainwaring \& Scully (1995), stable roots of a party in the society and stable patterns of competition between different parties are not too different in societies that parties are well entrenched. Most electorates support the same party and in various elections spanning a long period of time. Janda (2006) used stable organization to describe the rate at which a party has experienced mergers and splits as a variable to measure the extent to which political parties had existed and survived as a stable organization.

Institutions reduce the rate of uncertainties by putting structures in place in our daily activities. Institutionalization refers to the development whereby a practice or an organization becomes adequately established and extensively known or even globally accepted (Mainwaring \& Torcal, 2006).

Mainwaring \& Torcal (2006) suggest different dimensions. According to them, the hallmark of more institutionalized parties is stability, which implies regular patterns of party competition, established roots in the society and a connection between the party and the electorates. Those who participate in politics perceive political parties as necessary, independent and legitimate institutions in the democratic process. This implies that institutionalized parties are relatively stable and less, if at all, polarized (Mainwaring \& Zoco, 2007, Webb \& Holliday, 2002).

Scholars in party politics often use the concept of "institutionalization" to ascertain the extent of party development. Mainwaring \& Torcal (2006) in this regards assert that "an institutionalized party system, then is one in which actors develop expectations and behaviours based on the premise that the fundamental contours and rules of party competition and behaviour will prevail into unforeseeable future. In an institutionalized party system, there is stability in who the main parties are and how they behave".

The critical pillars of institutionalization, therefore, are the extent of consolidation, regularity, predictability and systemness of political competition or party politics. Though Mainwaring \&Torcal (2006) emphatically focused on party system institutionalization, the various dimensions by which this was analysed implies consolidation and stable patterns of interactions between parties. Stability and forms of competition among parties depend largely on factors such as organizational development, independence of party organizations as well as the extent to which they are rooted and viewed as legitimate within the society in which they operate (Webb \& Holliday, 2002).

In addition to the overwhelming consensus on the crucial role of political parties in a democratic system, another major requirement is the extent to which they are institutionalized ( Alfa, P.I,Yusoff, K.Z, Rajanthiran, S.P (2017) 2017). It is pertinent to note that competitive multiparty politics does not simply imply the existence of several political parties in a given country (Abeje, 2013). There could be many political parties in a country without any meaningful competition because of the dominance of one political party. Party system refers to where there is competitive party politics as well as democratic competition. A party system is said to be institutionalized if it is characterized by the presence of two or more autonomous political parties that participate actively in the struggle for power with reasonable electoral outcome. (Abeje, 2013). Opposition political parties are partisan political institutions which are deliberately put in place to temper the excesses of the party in power while at the same time pursuing legislative as well as presidential offices. Democracy, therefore is said to be genuine when the ruling party is checked by effective opposition (Carothers, 2006). This provides viable alternatives to the ruling party, facilitate debates concerning policies and makes the government to be accountable. Strong opposition prevents the government from sliding into authoritarianism and mitigate abuse of power through incumbency (Bogaards, 2004, Hislope\&Mughan, 2012, Alfa et al, 2017).

In view of the above, the ability of political parties to contribute to democratic consolidation depends, to a large extent, on at least three basic qualities of party systems that have bearing on the functioning of 
democratic governance (Baer, 1993). These are: the party system's level of institutionalization; their extent of fragmentation; and the degree to which they are polarised ( Mainwaring \& Torcal, 2006).

Reilly (2008) came up with the factors that negate the ability of political parties to discharge their democratic responsibilities particularly in transitional democracies. These are: poor institutionalization and limited membership, shifting of support base and weak policy capacity; they are built around personal and other parochial sentiments such as ethnic affinities and as such lack national outlook; they are characteristically thin organizations that are only active during elections. More often than not, they lack a comprehensive ideology; they do not represent any clear policy agenda; they do not exhibit the required discipline to build effective synergy in the parliament (Abeje,2013).

\section{Discussion}

Party politics in Nigeria, particularly in the Fourth Republic, is faced with a plethora of bottlenecks which negate party institutionalization. Some of the pitfalls of party politics and political parties that undermine the prospects of party institutionalization in Nigeria are modestly discussed below:

\subsection{Dysfunctional Evolution}

The way and manner political parties emerge in Nigeria especially in the recent period tend to negate their prospects for institutionalization and ability to guarantee political stability and consolidate democracy. The activities of political parties that have been operating in Nigeria since the commencement of the Fourth Republic are diametrically opposed to those of the established democratic norms (Omoruyi, 2016).

The way they evolved has no correlation with what we are familiar with in the extant literature. The fluidity and unstable character of their composition portray them as mere vehicles of regime change from military governance to civilian rule and obviously lack the capacity to resolve the persistent political issues tormenting the Nigerian state (Omoruyi, 2016).

\subsection{Lack of Unity and Focus}

An in depth examination of the way the Nigerian political parties have performed since the beginning of the Fourth Republic shows that they are incapable of addressing the various problems facing the country. Since the Fourth Republic began, political parties have been enmeshed in unhealthy competition with one another. Party factions are more in competition with themselves than with another party (Omoruyi, 2016). The situation is so dismal to the extent that the three major parties that operated between 1999-2003 manifested ethnic inclination and regionalist tendencies which was exhibited in the patterns of electoral prospects. These tendencies make party institutionalization a herculean task.

\subsection{Involvement in Electoral Malpractices}

Another crucial issue is the manner in which the political parties manipulate the electoral processes in their area of strength. It has been revealed by several researches that the parties engage in rigging and other electoral fraud. The cases of the 2003 and 2007 general elections are classical examples having sparked off post-election crisis and instability in different parts of the country (Omotola, 2009). To exacerbate the situation, the political parties perpetrated the fraud in collaboration with the law enforcement agents and INEC which ordinarily should have been a neutral arbiter in the electoral process.

\subsection{Abysmal lack of Internal Party Democracy}

Furthermore, Nigerian political parties have failed to maintain a harmonious relationship at the intraparty and inter party levels. Intraparty squabbles have always threatened the parties to extinction or caused schism of disturbing magnitude. This situation compelled many of the party stalwarts to defect or remain ambivalent. Such founding members in the PDP included the Late Sunday Awoniyi, Solomon Lar, Alex Ekwueme among others. The situation was not better in other parties like the Alliance for 
Democracy (AD) (Omotola, 2009). There is no mincing words that the above level of internal party democracy and party institutionalization has far-reaching implication for democratic consolidation. The problems besetting Nigerian political parties are so gross to the extent that if they are not remedied, they will not be better positioned to make meaningful contributions to democratic stability and consolidation.

\subsection{Inter-Governmental Disharmony}

The bottlenecks confronting Nigerian parties manifest in the sphere of governance, especially in InterGovernmental Relations. The executive and legislative stalemate over budget presentation, approval of appointments which in some instances cause threats of impeachment of the executives by the legislatures are a few instance. This came to climax in August 2002 when the House of Representatives served impeachment notice on Present Obasanjo and across the federation indicating disastrous implication for democratic stability. The poor level of party institutionalization became apparent in the ineffective manner in which the parties handle crises. Crises pervaded the states and this is so worrisome because even the states where the executives and majority in the legislature have common party affiliation were equally engrossed in the crises leading to threats of impeachment on the executives (Omotola,2010).

\subsection{Political Violence}

The implicit pitfalls of the political parties to play politics according to the rules in their internal affairs as well as the larger political entity have led to the politically motivated killings across political divide. The consequences of such conflicts have been perennial collapse of the political order resulting to pervasive instability all over the country and monumental loss of lives and property. Invariably, the focus of government and hard-earned resources have been wasted on conflict management instead of development agenda (Omotola, 2015).

\subsection{Lack of Ideological Foundation}

One major problems confronting Nigeria's democracy is ideological deficit. Ideology should be the basis for party operations, be an instrument for mobilization, conflict management, and identification and guide the actions and judgement of individuals (Omotola, 2007).Even though Nigerian political parties have programs from where their ideological disposition could be deduced, there is no clear cut distinction between the party programs of the various political parties and by implication, it is difficult to pin point their ideological differences.

The above situation is the reality with the Fourth Republic political parties unlike the parties of the First and Second Republics that were known with a measure of identifiable ideologies. In the same vein, the pattern and nature of political competition have little or no regards for ideological consideration due the attitude of the elite and the state. Rather, primordial cleavages becloud the entire process. That is the reason why the manifesto of the party that capture power is often relegated to the background and governance is at the capricious whims of the those in positions of authority. The situation has led to political vagrancy which implies a situation by which politicians defect from one party to another. These portend negative consequences for party institutionalization (Omotola, 2010).

\subsection{Indiscipline}

The gross exhibition of indiscipline by Nigerian parties is another causative factor that negate party institutionalization. This is evident in the high degree of internal party skirmishes and stalemate in the parties often to irreconcilable magnitude. The PDP and the APC have experienced these tremendously in the Fourth Republic. This has almost torn the parties into shreds even when the issues involved are such that could have been resolved amicably as a members of the same political family. The impeachment saga of August 2002 and the feud generated by the tenure elongation stalemate which led to the defection of the former Vice President Atiku Abubakar are examples of intraparty imbroglio of disturbing frequencies (Alfa et al, 2017). 
The trend is compounded by the lack of internal party democracy in the parties. This manifests in the mockery of party primaries where candidates are imposed leading the grievances. For instances, presidential aspirants on the platform of the ANPP (a branch of the current APC) of Southern extraction staged a walk out of the party's convention in Abuja in 2003, alleging that the choice of Muhammadu Buhari was premeditated. The situation in the PDP was not different as it was orchestrated to give Obasanjo the then president an advantage over other challengers (Alfa, et al,2017). In the PDP the force of incumbency was at play as the president used its might to return the serving party officers particularly his acolytes at its 2005 convention scheming out all opposition elements in the party. The process of nomination of flag bearers for the PDP prior to the 2007 elections were the most curious as the victorious candidates who were in the political "good books" of the party barons had their names removed and substituted by the favoured candidates (Omotola, 2010).

\subsection{Elite polarization}

Another key factor that is pivotal to the problem is the antagonism of the elite occasioned by the character of the state and the nature of the political contestation. The absence of internal party democracy in the current parties leads to marginalization of some party members . Ultimately, some members defect from the party to join parties where they can actualise their ambition. There is a lot of disunity in the parties due to the lack of internal party democracy and selfish interest. The various splits such as the nPDP and rAPC are fall outs of lack of internal party democracy the state is seen as the sure means of wealth and when the elites lost out the struggle, they pull out of the party and embark on antidemocratic conduct that stunt party institutionalization and undermine democratic consolidation (Alfa et al, 2017).

\section{Conclusion}

Party institutionalization is an essential condition for democratic consolidation in Nigeria's. The character of party politics in Nigeria's Fourth Republic make the prospects of party institutionalization remote. To redress this situation, it is pertinent to start with examining of the character of the Nigerian state. This entails an interrogation of the reasons why power acquisition remains central to the conflicts between different groups in the country at all levels. One tenable explanation for this is that power and resources are concentrated in the hands of the federal government. There is need for the decentralization and devolution of power at the federal and state as far as their control over resource allocation is concerned. This can reduce the cut throat competition for power among the political elites at all strata of governance (Junaidi, 2011).

Nigerian political parties should strive to meet the dictates opined by Baer (1993) for party institutionalization which are organizational vitality, organizational interdependence, stable factions and integrative community life. They must ensure that there should be a high degree of stability and regularity of party competitions which are relatively lacking. The parties must strive to maintain effective roots in the society to reinforce and stabilize the institutionalised system, establish and sustain effective party organizations instead of their current practices of operating as electoral instruments for actualization of the interests of personal leaders. This would ultimately enhance their legitimacy among the entire citizenry (Mainwaring, 1999). There is a critical need for the emergence of a genuinely nationalistic and committed leadership with great focus and foresight. Such a crop of leaders would be interested in governance that would address the yearnings and aspirations of the citizens. This brand of leadership is also necessary to manage the affairs of the political parties and other subgroups within the polity in order provide consensus building among critical political stakeholders on issues of national relevance.

Citizenship education that dwell on the values of unity, hard work, accommodation and discipline should be vigorously carried out. On this premise, internal reforms in the parties should be carried out with emphasis on party discipline, cohesiveness and the adherence to the tenets of internal party democracy by all political parties. Such reforms should also entail regulation and control of party 
finance (Omotola , 2010).

The constitutional provisions should enhance the powers of INEC to supervise and regulate the administration and activities of political parties. INEC should be given the power to enforce the doctrines of internal party democracy and also maintain a healthy interparty competition. INEC or other external regulatory bodies should be made to ensure that the abuse of incumbency especially with regards to non tolerance of opposition should be forestalled.

Efficient intraparty and inter party deliberations that would entrench a culture of cooperation and iron out areas of conflict and provide a level playing ground. A new political culture and legal framework should be cultivated to anchor party politics on the basis of constitutional government, separation of powers and the rule of law. The party structure and mode of administration should be decentralised with the various strata enjoying a measure of autonomy within its area of competition as enshrined in the party's constitution with clauses that would guarantee checks and balances by the other strata of the party. Intraparty democracy should be observed in the affairs of party particularly in their processes of candidate selection or nomination'. In this regards, the adoption of the direct primaries by the APC to ensure that registered members of the party participate in candidate selection process is a commendable step. The plan of the PDP to adopt the same strategy is equally heart-warming. Party discipline and due process should be enforced to enhance cohesion as these are the bedrock upon which party institutionalization and democratic consolidation thrive. To achieve this, the prescriptions that would lead to the attainment of an enviable democratic system, the provisions of Chapters 1 \& 5 of the 1999 Constitution of the Federal Republic of Nigeria should be religiously observed by the political parties.

As veritable tools for managing diversity, the composition of delegates to party Congresses and Conventions at the ward, local government, state national levels should reflect the various groups in the party and anchored on elective democratic principles.

When these prescriptions are enforced, parties will become institutionalized and well positioned to perform their roles in Nigeria's Fourth Republic and beyond.

\section{References}

Abeje, A (2013) Party System Institutionalization and the Prospects of Democratic Consolidation in Ethiopia.Europian Scientific Journal, 5(23) 315-328.

Alfa, P.I, Yusoff, K.Z, Rajanthiran, S.P (2017) Political Parties and the Quest for Democratic Sustenance in Nigeria's Fourth Republic. International Journal of Public Administration and Management, Vol. 4(1) 58-63.

Baer, D.L (1993) Who Has The Body? Party Institutionalization and Theories of Party Organization. American Review of Politics, Vol 14, pp 1-38.

Bogaards, M (2004) Counting Parties and Identifying Dominant Party Systems in Africa. European Journal of Political Research, Vol. 43 (2) 173-197.

Carothers, T (2006) Confronting the Weakest Link: Aiding Political Parties in New Democracies. Carmegie Endowment for International Peace: Washington D..C.

Constitution of the Federal Republic of Nigeria (1999) Third Alteration.

Hislope, R and Mughan, A (2012) Introduction Comparative Politics: The State and its Challenges. New York: Cambridge University Press.

Hofmeister, W and Grabow, K (2011) Political Parties: Functions and Organization in Democratic Societies, Singapore: Konrad Adenauer.

Ibeanu, O (2013) Regulating Nigerian Political Parties: Role of Independent National Electoral Commission (INEC); Being a paper presented at the National Conference on Political Parties and the Future of Nigeria, organised by the National Institute for Policy and Strategic Studies (NIPSS), Kuru.

Janda, K (2006) How Nations Govern Political Parties. Paper presented at the 20th World Congress of the International Political Science Association, Fukuoka, Japan. 
Mainwaring, S \& Scully, T (eds) (1995). Building Democratic Institutions: Party Systems in Latin America. Stanford CA: Stanford University Press.

Mainwaring, S (1999). Rethinking Party Systems in the Third Wave of Democratization: The Case of Brazil. StandfordCalifornia: Stanford University Press.

Mainwaring, S. and Torcal, M. (2006) 'Party system institutionalization and party system theory after the third wave of democratization', in R. S. Katz andW. Crotty (eds) Handbook of Party Politics, London, Thousand Oaks, CA and New Delhi: Sage, pp. 204-27.

Mainwaring, S. and Zoco, E. (2007) 'Political sequences and the stabilization of interparty competition: electoral volatility in old and new democracies', Party Politics $13(2)$ : $155-78$

Obi, C (2000) Last Card: Can Nigeria Survive Another Political Transition? Africa Journal of Political Science 5 (2) pp 67-86.

O' Donnell, G and Schmitter, P.C (2000) The Dynamics of Democratization: A Comparative Approach. London. Continuum. pp 20-24.

Omoruyi, A (2016) Internal Party Conflicts: The Effects of Internal Party Democracy in Nigeria's Political Parties- The Forward. Retrieved Fromhttps://www.linkedin.com/pulse/internal party conflicts-effect-lack-democracy-nigeria-aigbe

Omotola, J. (2009). Nigerian Parties and Political Ideology. Journal of Alternative Perspectives in the Social Sciences, 1(3), 612-634.

Omotola, J.S (2015) Political Parties and the Quest for Political Stability in Nigeria, Taiwan Journal of Democracy, Vol 6 (2) pp 125-145.

Omotola, S (2007) Godfathers and the 2007 Nigeria's Elections. Journal of African Elections,134-154.

Reilly, B (2008), 'Introduction' in Benjamin Reilly and Per Nordlund (eds.), Political Parties in Conflict-Prone Societies: Regulation, Engineering and Democratic Development (Tokyo: United Nations University Press.

Sanches, E.R (2014) Explaining Party System Institutionalization in Africa: From a Broad Comparison to a Focus on Mozambique and Zambia: University of Lisbon.

Sartori, G (1976) Parties and Party Systems: A Framework for Analysis. Vol.1 (London: Cambridge University Press.

Shively, W.P (2001) Power and Choice: An Introduction to Political Science. New York: Mc-GrawHill.

Tenuche, M (2011), The Albatross Called Primary Elections and Political Succession in Nigeria. Canadian Journal of Social Science, Vol 7,No 4, pp 121- 130.

Thurston, A (2015) Background to Nigeria's 2015: A Report of the CSIS Africa.

Webb, D., David M. F. and Holliday, L. (2002). Political parties in advanced industrial democracies. Oxford: Oxford University Press. 